\title{
Impact of Strategic Cost Analysis on Accounting Information
}

\author{
Dr. Abubkr Ahmed Elhadi Abdelraheem \\ Associate Professor - Department of Accounting \\ Faculty of Managerial and Financial Sciences - Peace University - Sudan \\ Dr. Badreldin Elhadi Ahmed Serajeldin \\ Associate Professor, Department of Accounting \\ Faculty of Managerial and Financial Sciences, Peace University, Sudan \\ Aldouma Abdallah Abdalrahman Jedo \\ Lecturer, Department of Accounting \\ Faculty of Managerial and Financial Sciences, Peace University, Sudan
}

\begin{abstract}
This study handles impact of strategic cost analysis on accounting information (field study on engineering industries Companies - Khartoum State), the study aimed to understand the concept of strategic cost analysis and the concept and characteristics of accounting information. The study test one hypothesis following: There is a statistically significant relationship between the application of strategic costs analysis and accounting information and hypothesis is achieved. The study reached some findings from which: strategic cost analysis contributes to the provision of appropriate information for decision making, Strategic cost analysis contributes to reducing the costs of different activities, strategic cost analysis contributes to providing information about activities that do not add value to the product, the study recommended following: care should be taken to apply the types of strategic cost analysis to obtain product information at all stages, must be applied the types of strategic cost analysis with modern cost methods to reduce the total cost of production.
\end{abstract}

Keywords: Strategic Cost Analysis, accounting information.

\section{Introduction}

At present, the industrial companies suffer from the intense competition they can get out of business. The basic age of competition, which can be controlled is the cost component, there are many strategies cost methods , including: activity based costing, target costing, just in time, which are associated with many developmental methods, including: management of activities, value engineering, and continuing attempts to find new ways to reduce costs through the value chain and product life cycle, so this study examines the impact of strategic cost analysis on accounting information that helps in costs making decisions.

\section{Study Problem}

Problem of study is following questions:

What is the impact of strategic cost analysis on accounting information?

$>$ Is there a statistically significant relationship between value chain analysis and accounting information?

$>$ Is there a statistically significant relationship between strategic position analysis and accounting information?

$>$ Is there a statistically significant relationship between cost drives and accounting information?

\section{Objectives of study}

Understand the concept of strategic cost analysis and the concept and characteristics of accounting information.

$>$ Identify types of strategic costs analysis

\section{Hypothesis of study}

The researcher tries to test the following hypothesis: There is a statistically significant relationship between the application of strategic costs analysis and accounting information. 


\section{Theoretical framework}

\section{Concept of strategic cost analysis}

The strategic cost analysis is one of the approaches used by cost accounting when dealing with strategic issues, especially after it has become necessary for the senior management of the establishment to need attention to strategic thinking so that it can interact and adapt to the environment in which it is active and affected by the emergence of technological and economic changes, For costing in providing cost data for the preparation of plans that provide competitive advantage to the enterprise, as it is difficult for current cost accounting methods to provide such data (Nagati,1995) $^{1}$. The strategic cost analysis is particularly important in analyzing the internal environment to identify strengths and weaknesses. It is also important in analyzing the external environment to achieve competitive advantages. The strategic cost analysis plays an important role in determining the quality of the most attractive industries in the market (Tony, 1996) ${ }^{2}$.Cost analysis is an approach that tries to look at all the activities of the entity as a whole and the relationships between those activities and the impact of these activities on each other. Considering that each activity is cost, cost management will be carried out comprehensively in an effort to achieve continuous cost reduction (Mohamed,2010).

\section{Objectives of strategic cost analysis}

The strategic cost analysis aims at following :(Mahi,2011)

A good understanding of the strategic factors in order to make the company able to formulate its strategic plans well in order to achieve continuous competitive advantages. The strategic factors can be determined by analyzing the external environment. The analysis of the external environment is focused on the international, regional or local market.

Analysis of the business environment: It includes the identification of the technology used, the new entrants in the industry and their impact on the market, the analysis of the strategic cost engines, and the use of external and internal strategic factors, including a series of value chain analysis, target cost.
$>$ Provide a good framework for allocation of resources between activities, this framework includes the identification of value activities within and outside the company.

Determine the sources of profits in companies and this is done by measuring the cost of strategic business units such as services, customers, production lines, to determine profitability, and the possibility of improvement and continuous development using the entrance cost of activity.

\section{Types of strategic cost analysis}

The adoption of the concept of strategic cost analysis transforms companies from the internal cost vision to the external vision of what costs should be, helping to achieve the strategic perspective of cost reduction. The strategic cost analysis is based on three types of analysis (Shank,1989) ${ }^{\mathbf{5}}$.

\section{Value chain analysis}

Value chain analysis is a tool for diagnosing enterprise activities, continuous improvement, multidimensional assessment including analysis (product cash flow, information flow, and management), and control of the value chain provides a mechanism to draw the attention of management and others to the opportunity for continuous improvement in all Stages of value chain (Andrew,2009) 6.

The value chain is the process of strategically dividing the entity into a range of activities to understand cost behavior (Matthias, 2008) ${ }^{7}$.value chain is a sequential set of activities and processes carried out by the entity during the life cycle of the product in order to find the real citizen to reduce the cost and strengthen the competitiveness of the entity (Atef,2003) ${ }^{\mathbf{8}}$. The value chain consists of two sets activities (Mahi,2011) ${ }^{\mathbf{9}}$ :

$>$ Main activities: It consists of five subsidiary activities: internal supplies, operations, product outputs, marketing, sales, and service.

$>$ Supporting activities: It consists of four subactivities namely the company's core structure, human resource management, development Technologies, and inputs. 


\section{Strategic position analysis}

The strategic position refers to the company's position in its competitive environment, and there are three fundamentals that determine the strategic position is the basis of product synthesis (product diversity), the basis of needs (the differentiation between all Consumer needs), customer access basis (distribution methods (Abdul Sattar, 2009) ${ }^{10}$.

\section{Cost driver's analysis:}

Cost factors are those factors that cause the cost of an activity to occur and explain the causal relationship between the output of the activity and its consumption of its own resources, such as the degree of energy utilization, the number of times of transport service, maintenance hours and the number of direct working hours. Operational cost, procedural cost drivers, structural cost factors, general cost drivers (Salem, 2009) ${ }^{11}$.

\section{Accounting information and characteristics}

Accounting information is all quantitative and nonquantitative information relating to economic events that are processed and reported in the financial statements, operating plans and reports used internally $\left(\right.$ Ziad,2010) ${ }^{12}$.

It is not necessary that the accounting data be converted to information processed and operated only, but became to achieve two conditions until the accounting data become information (Abdul Razzaq,2003) ${ }^{13}$.

The resulting information should reduce the degree of uncertainty of the decision - maker, by reducing the number of alternatives available to the decision - maker.

$>$ The resulting information should increase the knowledge of the decision-maker, in the case of failure to achieve the first condition, where it can benefit from the knowledge added to make other decisions in the future .In order for the accounting information to achieve its objectives, which is the primary objective of the decision-making user, it is necessary to have a set of characteristics that can be used as a basis for assessing the quality of the accounting information. The characteristics of the accounting information can be divided into the following (Nihad,2011) ${ }^{\mathbf{1 4}}$ :

\section{Main characteristics:}

Relevance: The ability of information to make a change in the direction of a particular user's decision. To make the information relevant, the following secondary characteristics are required: -

Timeliness: Provide accounting information in a timely manner before losing its usefulness or ability to influence the decision-making process.

$>$ predictive value of information: accounting information that has the greatest predictive capacity is more suitable for information users.

> Reclassification capability: Appropriate accounting information has a retrospective value when it has the ability to change or correct current or future expectations.

Reliability: Reliability is meant to correct information as a basis on which the decision-maker can rely on prediction. This property consists of three subcharacteristics:

$>$ The property of verifiable: in the sense that the information can be validated.

$>$ The property of neutrality and impartiality: any lack of bias in the process of obtaining information or not intentionally configured can serve a user without another.

$>$ The property of honesty in expression: means a high degree of congruence between measurements and phenomena to be reported.

\section{Secondary characteristics:}

Stability property: is the application of the same accounting procedures on similar events concepts One project from time to time Symmetry and comparability: Symmetry means the use of the same procedures and measurement concepts and the same methods of disclosure between different enterprises.

\section{Results \& Discussion:}

The study sample includes Engineering Industries Companies - Khartoum State. The researcher distributed (150) questionnaire forms among some of the workers in the field selected randomly (139) Forms were collected as 93\%. (SPSS) used for analyzing the relevant data. The researcher used 
statistical methods following: median, and Chi-Square test the hypothesis.

Table (1): Through table (1), the level of significance Chi-Square test (.000) less than the significance level 0.05 , This shows that There is a statistically significant relationship between applied the strategic costs analysis and accounting information., therefore the hypothesis is achieved.

Table (1)

\begin{tabular}{|l|l|l|l|l|}
\hline \multicolumn{1}{|c|}{ Phrases } & Median & explanation & Chi-Square & Asymp. Sig \\
\hline $\begin{array}{l}\text { Strategic cost analysis contributes to the } \\
\text { provision of appropriate accounting } \\
\text { information for decision-making }\end{array}$ & 5 & Strongly Agree & 339.143 & .000 \\
\hline $\begin{array}{l}\text { Strategic cost analysis contributes to the } \\
\text { provision of competitor information. }\end{array}$ & 4 & Agree & 238.036 & .000 \\
\hline $\begin{array}{l}\text { Value chain analysis contributes to the } \\
\text { provision of accounting information on } \\
\text { the Company's activities and how to } \\
\text { improve them. }\end{array}$ & Strongly Agree & 353.536 & .000 \\
\hline $\begin{array}{l}\text { Strategic Position Analysis contributes to } \\
\text { the provision of accounting information } \\
\text { on the Company's products and their } \\
\text { diversity to meet customer needs. }\end{array}$ & 5 & Strongly Agree & 256.964 & .000 \\
\hline $\begin{array}{l}\text { Cost-driver's analysis contributes to the } \\
\text { provision of accounting information on } \\
\text { the main causes of the cost of the } \\
\text { product. }\end{array}$ & 5 & Strongly Agree & 154.536 & .000 \\
\hline
\end{tabular}

\section{Findings:}

$>$ Strategic cost analysis contributes to the provision of appropriate information for decision making.

$>$ Strategic cost analysis contributes to reducing the costs of different activities.

$>$ Strategic cost analysis contributes to providing information about activities that do not add value to the product.

\section{Recommended:}

$>$ Care should be taken to apply the types of strategic cost analysis to obtain product information at all stages.

$>$ Must be applied the types of strategic cost analysis with modern cost methods to reduce the total cost of production.

\section{References}

(1) Nagati Ibrahim, (1995), Strategic Analysis as an Approach to Developing Cost Data under International Variables, Journal of Financial and
Commercial Studies, Faculty of Commerce, Cairo University, First Issue, pp 19-20.

(2) Tony Grundy, (1996) Cost is A Strategic Issue, Long Range Planning, Volume 29, P 60.

(3) Mohamed Naguib Osman, (2010) Use of strategic analysis of costs in electricity production companies to support competitiveness, $\mathrm{PhD}$ thesis in Accounting unpublished, Faculty of Commerce, Ain Shams University, p. 41.

${ }^{(4)}$ Mahi Sami Mohamed, (2011) Using Cost Management Approach to Decision Making in Insurance Companies - Applied Study, Master of Unpublished Accounting, Faculty of Commerce and Business Administration, Helwan University, p. 19.

${ }^{(5)}$ Shank Jhon K, (1989), Strategic Cost Management: New Wine or Just New Bottles, Journal of Management Accounting Research, Volume (1), p 50.

(6) Andrew Fearne, (2009) Sustainable Value Chain Analysis: A CaseStudy of South Australian Wine, 
Government of South Australia Annabel Mugford, of Baghdad College of Economic Sciences, P. 9. University, No. 22, p.

${ }^{(7)}$ Matthias Kannegiesser, (2008)Value Chain

${ }^{(11)}$ Salem Saeed Baajajah, (2009) Strategic Analysis Management in the Chemical Industry -Global of Costs and its Applicability Study of its Value Chain Planning of Commodities, (Heidelberg, Physica-Verlag), P 11.

${ }^{(8)}$ Atef Abdel-Majid Abdel-Rahman, (2003), Proposed Framework for Cost Analysis and Management from a Strategic Perspective with a view to Maximizing the Value of the Establishment, Journal of Contemporary Business Research, Faculty of Commerce, Sohag University, Vol. (17), No. 2, p.

(9) Mahi Sami Mohamed, (2011) Using Cost Management Approach to Decision Making in Insurance Companies - Applied Study, Master of Unpublished Accounting, Faculty of Commerce and Business Administration, Helwan University, p. 310.

${ }^{(10)}$ Abdul Sattar Al-Sayah, (2009) Strategic alignment and its impact in determining the strategic position of business associations, Journal Application to Cement Companies in the Kingdom of Saudi Arabia, Journal of Commercial Research, Faculty of Commerce, Zagazig University, Vol. 31, No. 1, p. 111.

${ }^{(12)}$ Ziad Abdel-Karim El-Kady, (2010), Design of Management Information Systems and Accounting, (Amman: Arab Society Library for Publishing), $\mathrm{p}$.

${ }^{(13)}$ Abdul Razzaq Mohammed Kassem, (2003), computerized accounting information systems, (Oman: International Scientific Publishing House and Distribution), page 18.

${ }^{(14)}$ Nihad Ishaq Abdel Salam, (2011), The Role of Accounting Information in the Rationalization of Capital Expenditure Decisions, Master Thesis in Unpublished Accounting, Faculty of Commerce, Islamic University, Gaza, pp. 20-23. 